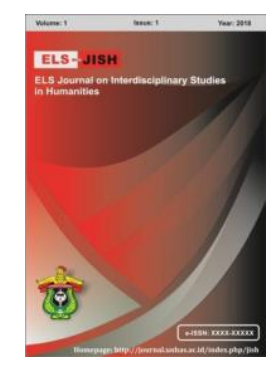

ELS-JISH

ELS Journal on Interdisciplinary Studies on Humanities

Volume 3 Issue 3, 2020

ISSN (print) : 2621-0843

ISSN (online) : 2621-0835

Homepage : http://journal.unhas.ac.id/index.php/jish

\title{
Ideological Dimension in Bunga' lalang : An Anthropological Linguistic Study
}

\author{
Magfirah Thayyib ${ }^{1}$, Burhanuddin Arafah ${ }^{2}$, Martin L. Manda ${ }^{3}$, \\ Fathu Rahman ${ }^{4}$ \\ ${ }^{1}$ magfirah thayyib@yahoo.com
}

\begin{abstract}
This research aims to reveal the ideological dimension of bunga' lalang tradition through the analysis of its two rituals namely mappammula ta'pa and mappammula mantanang. Bunga' lalang is an agricultural tradition which exists in Luwu society, South Sulawesi, Indonesia. It refers to the series of rituals done by a bunga' lalang (path opener) in every rice farming stage. This research employed descriptive qualitative method. The primary data were obtained through observation and interview while the secondary data were obtained through documentation. The data were analyzed using the combined/reviewed steps in ideological dimension analysis of social semiotics and dialectical ecolinguistics. There are several ideological dimensions in bunga' lalang tradition through the analysis of two ritual discourses namely mappammula ta'pa and mappammula mantanang. The ideological dimensions revealed are classified into cognitive system, cultural assumption/belief, and mental/psychological system. All reflected the ideology of Luwu people/society in which bunga' lalang tradition exists.
\end{abstract}

Keywords: Ideological Dimension, Bunga' Lalang , Anthropological Linguistic Study.

How to cite: Thayyib, M., et al. (2020). Ideological Dimension in Bunga' lalang : An Anthropological Linguistic Study. ELS-Journal on Interdisciplinary Studies in Humanities, 3 (3), 467-475. DOI: https://doi.org/10.34050/elsjish.v3i3.11352

\section{Introduction}

Bunga' lalang is an agricultural tradition which exists in Luwu society, South Sulawesi, Indonesia. It is an agricultural tradition referring to the series of rituals done by a bunga' lalang (path opener) in the beginning of every rice farming stage. It aims for fine cultivation of all ricefields in one village. The rituals of bunga' lalang consist of verbal part and non-verbal part.

Many agricultural traditions similar to bunga' lalang exist in Indonesia. Some of them have been studied due to their special linguistic features and, mainly, their valuable contents (e.g. Sumitri (2015); Badaruddin (2016); Abdullah \& Suparno (2016); Jumadi, et al (2016); Ola (2017); Harianto, et al (2017); Rukesi \& Sunoto (2017).

${ }^{1}$ Intitut Agama Islam Negeri Palopo, Indonesia

2,3,4 Hasanuddin University, Indonesia. 
For sure, bunga' lalang has its own features and valuable meanings including its ideological meaning. Ideological dimension is one of the essential parts of a society's culture. It can be utilized as a basis of identity reinforcement of the society. Hence, it is necessary to study bunga' lalang tradition, specifically to investigate all of its rituals' meanings. And accordingly, it is also necessary to take suitable approach/model to gain such purposes.

Thus, first of all, this research aims to review the steps in ideological dimension analysis of a language form especially for ritual discourse. Secondly, this research reveals the ideologiacal dimension of two rituals in bunga' lalang tradition namely mappammula ta'pa and mappammula mantanang using the reviewed analysis steps.

\section{Objective of the research}

This research aims to firstly review the steps in ideological dimension analysis of a language form and, secondly, to reveal the ideological dimension of two rituals in bunga' lalang tradition namely mappammula ta'pa and mappammula mantanang using the reviewed analysis steps

\section{Ideological Dimension Analysis}

Ideological dimension in this research is a term used for ideological meaning or the ideology(ies) in a language form/text/discourse. Ideology itself has been defined variously by the theorists. Ideology is a mental phenomena; something has to do with consciousness, subjective representations, beliefs, and ideas (Schieffellin, et al, 1998: 5). Ideology is the structure of the values and interests that informs any representation of reality (Hawkins, 2001: 4).

A language form reproduces ideology (Simpson, 1993: 5). It also happens to a discourse of a ritual/tradition. As an integrated form of social behavior, language will be inevitably and inextricably tied up with the socio-political context in which it functions. Language operates within this social dimension it must, of necessity reflect, and some would argue, construct ideology (Simpson, 1993: 5).

Anthropological linguistic sees a close relationship between language and culture (Mansyur \& Suherman, 2020). This study is the one considered more appropriate to find out as many meanings as possible of a tradition. Anthropological linguistics is search for the meanings in linguistic practices within wider cultural practices (Foley, 1997: 5). It has already proposed that a language form would be meaningful and give complete information if it is observed in its context. It still needs a clearer model of analysis.

One of the eminent model of understanding language or analyzing a language form/a discourse is Halliday and Hasan's social semiotics. In social semiotic view, language should be interpreted within a socio-cultural context, in which the culture itself is interpreted in semiotic terms (Halliday, 1978: 2). It recognizes text and context as the main aspects in understanding language.

The meaning of a text in social semiotics is obtained from the interpretation of textual metafunction. Then, context in social semiotics is divided into two, context of situation and context of culture. The context of situation is understood through field, tenor, and mode of discourse. While, the context of culture is the 
institutional and ideological backgrounds that give value to the text and constrain its interpretation (Halliday and Hasan, 1985: 49).

Another model of analyzing discourse that provides a space for ideological background is dialectical ecolinguistics by Bang and Door. A dialogue has a situation and happens in an environment called social praxis (Bang and Door, 1993: 7). A dialogue refers to text/discourse; a situation refers to context of situation; social praxis refers to outer dimensions/contexts: biological, sociological, and ideological.

The two models of social semiotics and dialectical ecolinguistics have the same gist with anthropological linguistics. They have parallel notion that a language form cannot be separated from its contextual use and its corresponding culture. They also facilitate the analysis of ideological dimension. Thus, in this research, the two models are combined to have clearer steps of analysis which results in comprehensive ideological dimension in bunga' lalang tradition.

Table 1. Associated chart of social semiotics \&dialectical ecolinguistics

\begin{tabular}{|c|c|c|c|c|c|c|c|c|c|}
\hline \multirow{3}{*}{$\begin{array}{c}\text { Social } \\
\text { Semiotics }\end{array}$} & \multirow{2}{*}{\multicolumn{3}{|c|}{ Text }} & \multicolumn{6}{|c|}{ Context } \\
\hline & & & & \multicolumn{3}{|c|}{ Context of Situation } & \multirow{2}{*}{\multicolumn{3}{|c|}{$\begin{array}{l}\text { Context of Culture: } \\
\text { Social and Ideological }\end{array}$}} \\
\hline & Ideational & Interpersonal & Textual & Field & Tenor & Mode & & & \\
\hline \multirow{2}{*}{$\begin{array}{c}\text { Dialectical } \\
\text { Ecolinguistics }\end{array}$} & \multicolumn{3}{|c|}{ Dialogue } & \multirow{2}{*}{\multicolumn{3}{|c|}{$\begin{array}{c}\text { Situation: Topos } \\
\text { Space (time and place) }\end{array}$}} & \multicolumn{3}{|c|}{ Social Praxis } \\
\hline & \multicolumn{3}{|c|}{ Subject(s) } & & & & Biologics & Sociologics & Ideologics \\
\hline The & & Text & & \multicolumn{3}{|c|}{ Situational Context } & Biological/ & \multicolumn{2}{|c|}{ Cultural Context } \\
\hline $\begin{array}{c}\text { Combined } \\
\text { Model }\end{array}$ & Ideational & Interpersonal & Textual & Field & Tenor & Mode & $\begin{array}{c}\text { Environmental } \\
\text { Context }\end{array}$ & Sociological & Ideological \\
\hline
\end{tabular}

In social semiotic model, ideological dimension is included in the context of culture. Butt, et al (2000: 3 ) describes the context of culture in social semiotics as: "when we think of differences in forms of address, in ceremonies, in politeness and in significant activities between one culture and another, we get some idea of the importance of context of culture in shaping meanings". It means that understanding the context of culture of a text automatically revealing the distinctive features of a culture in which the text is shaped.

Unfortunately, there is no a separate linguistic model of the context of culture offered by Halliday and Hasan (1985: 47). As well, there is no specific step in analyzing ideological dimension. But we can actually refers to the steps in which the situational context is analyzed. Another beneficial thing is that social semiotic model accommodates the analysis of tradition discourse like bunga' lalang rituals which consist of verbal and non-verbal parts.

In dialectical ecolinguistic model, ideological dimension is one of the three parts of social praxis. Ideological dimension is the mental aspect of a language form (Bang and Door, 1998: 10). It is about our individual or collective mental, cognitive, ideological and psychological systems (Bundsgaard and Steffensen, 2000: 11). Such details are beneficial in clarifying the steps in analyzing ideological dimension.

Combining the two models, the details of the ideological dimension analysis are: 1) treating the verbal part of the ritual as one semantic unit which culturalbased; 2) identifying all semantic units (word, phrase, clause) in the discourse which related to the society's culture especially the ones related to cognition, 
mental and psychological; 3) interpreting and making analogies of those semantic units based on the facts and information of the society's culture.

\section{Ideological Meaning in Mappammula Ta'pa Ritual}

From all rituals of rice farming, mappammula ta'pa is the most frequent one to be used to explain bunga' lalang . Bunga' lalang is defined by saying that no one can start to plow the ricefield if bunga' lalang has not started it/performed mappammula ta'pa. The word mappammula means 'start' and ta'pa literally means 'arrive/land'. In the clause of mappammula ta'pa, the meaning of ta'pa is extended to 'go to the ricefield to plow it'.

The discourse of mappammula ta'pa ritual:

Bunga' lalang brings his hoe and chooses a spot in the ricefield. He stands, looks down the soil on the spot and whispers:

'Kum sangammu to' jio tana, kim sangammu to' jao langi';

Kum mappammula, kum dipammulangang, napinjaji puang Allah Ta‘ala."

(Kum is your name who is in the land, Kim is your name who is in the sky; Kum begins, Kum is begun, made by Allah the Most High)

Then, by whispering Bismillahirrahmanirrahim, he hoes the soil somewhat turn around to the right - away from his body - and immediately looks at the sky. It is done three times.

There are non verbal actions and circumstances in mappammula ta'pa which identified to have cultural values and ideological meaning. The action of 'look down the soil' and 'look at the sky' at hoeing time are couple. It is similar to the couple words in the verbiage of 'kum' (who lives in the land) and 'kim' (who lives in the sky). From ideological view, mappammula ta'pa regards a life balance just like the position/relation between the land and the sky.

The action of 'take home the soil' with its circumstance of 'in the middle of the hoe rotations' is done to console the hoed soil - not to make it sad. It can be said that the psychological aspect of the hoed soil is cared even though it is inanimate. The soil is the element of nature which is primary in rice planting. The ideological background of it is respecting the nature.

The circumstance of 'away from his body' in hoeing the soil is explained as we cannot hoe ourselves. The psychological aspect of it is carefulness - not to hurt ourselves. It is a kind of self-respect. The last circumstance is (do the hoeing) 'three times'. It is said that odd number is believed to bring luck.

The action of 'whisper' which leads the verbiage has mental and psychological values. Whispering helps bunga' lalang to unify his soul and body and to focus on his intention. Whispering indicates the mildness in addressing the supernature and Allah Swt. In fact, all bunga' lalang whisper almost of their words (pau-pau). The words or mantra of kabunga'lalangang are only known by restricted group. According to Fathu Rahman (Rahman, 2018: 821) mantra is a collection of words that are believed to have mystical or magical powers.

The first part is called as mappisa'bi which means notifying others. Mappisa'bi is a mandatory part in every kabunga'lalangang activity. Mappisa'bi is done toward the nature and (peculiarly) toward the supernature. It is based on 
the belief on the existence of supernature in every place. The cultural values of mappisa'bi are respecting the supernatures and getting closer to them so they can be supportive toward the rice farming activities.

The literal meaning of the first two clauses in second verbal part is "kum begins to plow the soil, kum is also the one plowed'. The cultural meaning added deals with the word 'kum' which is (the physic of) the land/the soil and we, (human beings) are created from soil too. (Human who is created from) soil starts to plow the soil and the soil is also the one plowed. The actor and the goal are the same i.e. the soil.

Replacing human/actor/bunga' lalang as the soil means making the relation of the two becomes closer and unified. It exposes such ideal process of hoeing the soil in which the subject and the object are equal. Exposing the ideal processes of something is a kind of autosuggestion to ownself and others to go through such ideal ones and achieve the ideal goals. So, there is actually such an intention in the verbiage to have an ideal process of hoeing the soil but it is not stated directly.

The surface structure of the verbiage is said to have logical order. As well, the deep structure of the verbiage reveals logical thought pattern. Throughout the verbiage, after notifying the supernature, unifying with the nature, bunga' lalang surrenders all to Allah Swt. The cognitive and logical values are also obvious due to the configuration of the content of the verbiage.

\section{Ideological Meaning in Mappammula Mantanang Ritual}

Besides mappammula ta'pa, the activity which is usually included in the definition of bunga' lalang is mappammula mantanang. The people cannot plant the paddy if bunga' lalang has not started to plant it. Several changes in mantanang (paddy planting) methods influence the points of bunga' lalang ritual. Generally, there are two methods done by the farmers in Luwu namely indirect planting and direct planting.

Based on tradition, a bunga' lalang starts all the steps (of direct/indirect method). Bunga' lalang ideally performs a symbolic beginning for every steps in tempe' kabunga'lalangang. The other farmers usually follow to do the steps in their ricefields by mutual assistance. The activity of mappammula mantanang in the Encyclopedia of Luwu Culture is called 'mappammula taneng' (Anwar, 2007: 222).

\section{The discourse of mappammula mantanang ritual:}

Bunga' lalang stands in the corner of the ricefield. He looks around (from right to left) two times. He takes the paddy seeds with his right hand and whispers:

“kum sangammu to' jio tana, kim sangammu to' jao langi'; accing sangammu to' pare, na mu lao inde' lino mu disanga sawe manurung."

(Kum is your name who is in the land, Kim is your name who is in the sky, accing is your name-paddy, since you descend to this world, you are named sawe manurung)

Bunga' lalang continues to whisper: 
"ku tanang ko bine, na mu tuo, mimbua, malapu, nakatutui umma' na Nabi Muhammad napake makkasiwiang lako puang Allah Ta‘ala.”

(I plant you seed, so you grow, bear fruit, filled, being cared by the followers of the Prophet Muhammad, being used to worship to Allah the Most High)

Then, after a couple of seconds, he whispers again:

“kum mantanang, kum dipantanangngi; kiissi to' ditanang, kiissi to' mantanang, Barakka Laa Ilaha IIlallah."

(kum plants, kum is planted, filled is what planted, filled is who plants, Barakka Laa Ilaha Illallah)

By whispering Bismillahirrahmanirrahim, bunga' lalang sows the paddy seeds in seven spots.

There are several non verbal aspects in the ritual of mappamula mantanang which have cultural meaning including ideological meaning. The action of 'whisper' has the same meaning with the one in the discourse of mappammula ta'pa. It shows the sacred of the ritual also the focus and mildness of bunga' lalang in performing it.

The non verbal aspect is 'after a couple of seconds'. A pause needed to focus before sowing the seeds and find the right moment to do it. Before planting, bunga' lalang closes his eyes and uses his inner thought to see the paddy plants in all ricefields in the village have grown and born fine fruits. A bunga' lalang should also wait until everything is quiet - no sound and no wind. Then, it is a kind of focus on intention and autosuggestion; it contains composure and positivism.

The last non verbal aspect is 'in seven spot'. It is said as a part of tradition. 'Seven' in Tae' Language is 'pitu' or 'tuju' which has similar sound with the word 'mattuju' meaning directed/success which is better than other numbers. This is again a kind of positivism and autosuggestion that what is done will be success. Doing something in better/best practice will result in best output.

The first verbiage is mappisa'bi toward the spirit of the land and the sky as in mappammula ta'pa discourse and toward the paddy. The name of the land and the sky should be mentioned before sowing the seeds. The one mentioned, next, is the paddy which also refers to the seeds handled by bunga' lalang when mappisa'bi. The two names of paddy should be mentioned before planting.

The name of the paddy in heaven is 'accing' derived from 'mapaccing' which means 'clean'. Descending to this world, the name of the paddy is 'sawe manurung'. Literally, 'sawe' as adjective means proliferating and 'manurung' as noun means 'the one who descends'. So, the meaning of 'sawe manurung' is the one who descends and proliferates.

The name 'to manurung' in Luwu culture is commonly known as the term for a noble person who directly descends from heaven (Kesuma, 2015: 68). 'Sawe manurung' initially refers to all of us, human being then used for the paddy. It is related with the previous statement that actually the paddy is we ourselves; the paddy and us have the same God. 
The naming system of the paddy in which there is the name in heaven and in the world is actually quite common in Luwu culture. Many entities are said to have several names including their name in heaven and the world. The paddy actually has many names. The heroic figure of Luwu, Sawerigading, even has nine names; his name in heaven is Pamadalette; his names in the world are varied based on the place (Mallondjo, 2008: 3).

The purpose of addressing the paddy (seeds) is to appreciate/respect the paddy. Knowing and mentioning the real/complete/good name of someone or something psychologically make us closer to him/her/it. The name of the paddy in heaven which means 'clean' reflects 'chastity'; it is indeed a good name.

In the second verbiage, the clauses 'I plant you seed, so you grow, bear fruit, filled' are said as logical and ideal results. The clauses show the basic stages of rice farming to result in the paddy grains. Stating those ideal results of rice farming at early stage of planting is a kind of strong intention, autosuggestion, and positivism. The intention is oriented on the material result of paddy planting.

The clauses of 'being cared by the followers of the Prophet Muhammad, being used to worship to Allah the Most High' is said as the ideal/expected farmers-villagers' attitudes toward the result of rice farming i.e. the paddy grains. The intention in the second verbiage is extended to somewhat long term orientation of life. It reveals the futuristic cognitive of the people.

The third verbiage contains two parts of more figurative clauses. The clauses 'kum plants, kum is planted' have the same pattern with 'kum begins, kum is begun' in mappammula ta'pa discourse. As explained before, 'kum' which initially refers to (the spirit of) the land is used to refer to human/actor/bunga' lalang who plant/sow the seeds. So, the clauses culturally means (human who is created from) the soil plants, the soil is planted'. The cultural values of such pattern are equality with the nature.

The explanation of the clauses 'filled is what planted, filled is who plants' is that "before planting the paddy/sowing the seeds, we should have filled ourselves and the paddy". We should inspire ourselves and the paddy; we expect for the prosperity of the farmers and the paddy. The clauses contain enthusiasm, positivism, intention and autosuggestion. It is related to the explanation of the non verbal aspect 'after a couple of seconds' that before planting bunga' lalang sees the paddy has born fine fruits.

Overall, the verbiage exposes ideal processes and more on consequences of planting the paddy (seeds). The exposure is a kind of intention and autosuggestion to strive for ideal processes in order to achieve best results. Then, the positivism value is always engaged in the verbiage.

\section{Ideological Dimension in Bunga' Lalang}

The cognition of Luwu people reflected in bunga' lalang tradition, to some extent, is gratified due to some logical meanings of the verbal parts. The cognitive system frequently involves simple analogy based on symbolization. For example, odd number/quantity is a symbol of luckiness or successfulness. The cognitive system entails the process and result orientation. The result orientation is even futuristic; the people have long term orientation of life. 
The cultural assumptions/beliefs in two rituals of bunga' lalang are a supernature exists in every place and takes care of the place e.g. 'the spirit of the land'; supernature can be supportive toward the rice farming activities so they should be respected and notified (through mappisa'bi); human is created from soil; human and the soil (of the ricefield) are the same.

The mental/psychological systems are expressing and focusing (unifying soul and body) on intention/pray; mentioning the (good) name of something to get closer to it; having high positivism and doing frequent autosuggestion; regarding a life balance; having complete set of respect aspect (self respect, respect toward human being, supernature, nature, and glorification the God as the creator).

\section{Conclusion}

There are several of ideological dimensions in bunga' lalang tradition through the analysis of two ritual discourses namely mappammula ta'pa and mappammula mantanang. The ideological dimensions revealed are classified into cognitive system, cultural assumption/belief, and mental/psychological system. All reflected the ideology of Luwu people/society in which bunga' lalang tradition exists.

\section{References}

Abdullah \& Suparno, Darsita. (2016). Kebudayaan Petani Damar Pesisir Barat Krui: Perspektif Antropologi Linguistik. repository.uinjkt.ac.id. Retrieved on 17 July 2016.

Anwar, I. (2007). Ensiklopedi Kebudayaan Luwu. Palopo: Pustaka Sawerigading.

Badaruddin, M., S. (2016). The Meaning of Tulembang and Tupakbiring Mantras in the Life of Makassar Ethnic. International Journal of Linguistics, Literature and Culture, Vol. 2, No. 2, July 2016.

Bang, J., C.,. \& Door, J. (1993). Eco-linguistics: A Framework. In Alexander, Richard, et al (eds). AILA '93: Ecolinguistics: Problems, Theories and Methods. Odense: University of Odense.

Bang, Jorgen Chr. \& Door, Jorgen. (1998). Sprogteori IX: Language, Ecology and Truth - Dialogue and Dialects. Odense: Odense ELI Research Group.

Bundsgaard, Jeppe and Steffensen, Sune. (2000). The Dialectics of Ecological Morphology. In Lindo, Anna Vibeke and Bundsgaard, Jeppe (eds.). 2000.

Butt, David, et al. (2000).. Using Functional Grammar. Sydney: Macquarie University.

Foley, William A. (1997). Anthropological Linguistics: An Introduction. Oxford: Blackwell Publishers.

Halliday, M. A. K. (1978). Language as a Social Semiotics. London: Edward Arnold. 
Halliday. M. A. K. \& Hasan, R. (1985). Language, Context, and Text: Aspect of Language in a Social Semiotic Perspective. London: Oxford University Press.

Harianto, et al. (2017). The Meaning and Values of Tradition Dedeng Rice Harvest as Local Cultural Defense in Timbang Jaya Village Langkat Regency. International Journal of Academic Research in Business and Social Sciences. 2017, Vol. 7, No. 12.

Hawkins, B. (2001). Ideology, Metaphor and Iconographic Reference. In Dirven, et al. (eds.) 2001. Language and Ideology Vol. II. Philadelphia: John Benjamins.

Jumadi, et al. (2016). Antropolinguistik dalam Mantra Tradisi Mambuntang Masyarakat Dayak Maanyan di Lahan Basah. Kalimantan Selatan: Universitas Lambung Mangkurat.

Kesuma, Andi Ima. (2015). Legacy Tana Luwu. Makassar: Dinas Kebudayaan dan Pariwisata Provinsi Sulawesi Selatan.

Mallondjo, Siodja Daeng. (2008). Kedatuan Luwu. Palopo: Komunitas Sawerigading.

Mansyur, F. A., \& Suherman, L. A. (2020). The Function of Proverbs as Educational Media: Anthropological Linguistics on Wolio Proverbs. ELS Journal on Interdisciplinary Studies in Humanities, 3(2), 271-286. https://doi.org/10.34050/els-jish.v3i2.10505

Ola, Simon Sabon (2017). Meaning and Values of Agriculture Ritual Speech on Dawan Ethnic in Mollo District of South Central Timor. International Journal of Linguistics, Language and Culture, Vol. 3, No. 2, March 2017.

Rukesi and Sunoto. (2017). Nilai Budaya dalam Mantra Bercocok Tanam Padi di Desa Ronggo Kecamatan Jaken Kabupaten Pati Jawa Tengah: Kajian Fungsi Sastra. Basindo: Jurnal Kajian Bahasa, Sastra Indonesia, dan Pembelajarannya. Vol.1, No.1, April 2017.

Rahman, F. (2018). Literature of the Minority in South Sulawesi Endangered. Medwell Journals Medwell Publications, 13, 820-825.

Schieffellin, Bambi B., et al. (1998). Language Ideologies. New York: Oxford University Press.

Simpson, Paul. (1993). Language, Ideology and Point of View. London: Routledge.

Sumitri, Ni Wayan. (2015). The Traditional Oral Discourse of Vera of the Ethnic Rongga in East Manggarai in East Nusa Tenggara. Denpasar: Disertasi. Program Pascasarjana Universitas Udayana. 